\title{
Sevoflurane and fentanyl exert protective effect on cognitive function in aged rats via regulation of inflammatory response in the brain
}

\author{
Xin Zhao ${ }^{1}$, Peixiang $\mathrm{Li}^{2 \star}$ \\ ${ }^{1}$ First Department of Anesthesiology, Cangzhou Central Hospital, Hebei 061001, ${ }^{2}$ Anesthesia Department, Linzi District \\ People's Hospital, Huangonglu 139, Linzi, Zibo, Shandong 255400, China \\ *For correspondence: Email: rx1169@163.com
}

Sent for review: 13 November 2018

Revised accepted: 29 April 2019

\begin{abstract}
Purpose: To investigate the effects of sevoflurane and fentanyl on cognitive function in aged rats, and to determine the mechanism of action.

Methods: A total of 160 adult male Wistar rats were randomly assigned to four groups of 40 rats each. With the exception of control, the rats were surgically operated on. Sevoflurane group received sevoflurane (2\%) via inhalation for $2 \mathrm{~h} /$ day for 7 days, while the fentanyl group received fentanyl (50 $\mu \mathrm{g} / \mathrm{kg}$ body weight) for $1 \mathrm{~h}$ via their tail veins for 7 days. The cognitive function of the rats was evaluated by shuttle box and Morris water maze (MWM) tests, while interleukin-6 (IL-6), vascular endothelial growth factor (VEGF) and tumor necrosis factor $\alpha$ (TNF- $\alpha$ ) were evaluated using ELISA kits.

Results: The learning and memory latencies of the rats were significantly prolonged in surgery, with prolongation greater in sevoflurane and fentanyl groups than in control group; however, the latencies were significantly shorter in sevoflurane and fentanyl groups than in surgery group $(p<0.05)$. The levels of VEGF, IL-6 and TNF- $\alpha$ were significantly higher in the surgery, sevoflurane and fentanyl groups than in control group $(p<0.05)$.

Conclusion: Sevoflurane and fentanyl improve cognitive function in aged rats via a mechanism involving the regulation of inflammatory response in the brain.
\end{abstract}

Keywords: Sevoflurane, Fentanyl, Aged rats, Cognitive function, Inflammatory factors

\begin{abstract}
This is an Open Access article that uses a fund-ing model which does not charge readers or their institutions for access and distributed under the terms of the Creative Commons Attribution License (http://creativecommons.org/licenses/by/4.0) and the Budapest Open Access Initiative (http://www.budapestopenaccessinitiative.org/read), which permit unrestricted use, distribution, and reproduction in any medium, provided the original work is properly credited.
\end{abstract}

Tropical Journal of Pharmaceutical Research is indexed by Science Citation Index (SciSearch), Scopus, International Pharmaceutical Abstract, Chemical Abstracts, Embase, Index Copernicus, EBSCO, African Index Medicus, JournalSeek, Journal Citation Reports/Science Edition, Directory of Open Access Journals (DOAJ), African Journal Online, Bioline International, Open-J-Gate and Pharmacy Abstracts

\section{INTRODUCTION}

Cognitive function is an essential neurological activity which enables animals to adapt to their environment, receive and process information, and acquire knowledge and experience. According to statistics, about $25 \%$ of elderly patients develop postoperative cognitive dysfunctions which are characterized by changes in personality, social abilities and cognitive abilities [1]. The specific causes, and processes involved in patient postoperative cognition decline, especially in the elderly, have not been fully elucidated. However, it has been hypothesized that brain damage and suppression of central neurotransmitter function may be involved [2,3]. Anesthesia is an indispensable medical step in surgical procedures. However, 
the effect of anesthesia on cognitive ability, and the organs and molecules involved remain unclear. The aim of the present study was to investigate the effects of sevoflurane and fentanyl on cognitive function in aged rats, and to assess the underlying mechanism.

\section{EXPERIMENTAL}

\section{Materials and equipment}

Adult male Wistar rats were obtained from Nanjing Qinglongshan animal farm. Sevoflurane and fentanyl were products of Jiangsu Hengrui Medicine Co. Ltd, while VEGF, IL-6 and TNF- $\alpha$ kits were purchased from Beijing Lidman Biochemical Co. Ltd. Shuttle box and Morriswater maze were products of Anhui Zhenghua Biological Instrument Equipment Co. Ltd. Video monitoring and analysis system was purchased from Shanghai Xin Soft Information Technology Co. Ltd.

This research received approval from the Animal Ethical Committee of Anesthesia Department, Linzi District People's Hospital, Huangonglu 139, Linzi, Zibo, Shandong, China (approval no. 20186640), and was conducted in line with "Principles of Laboratory Animal Care" [4].

A total of 160 adult male Wistar rats $(300-500 \mathrm{~g})$ aged 20 months were randomly assigned to four groups of 40 rats each: control group, surgery group, sevoflurane group and fentanyl group. They were kept under standard conditions thus: $24 \mathrm{~h}$ light, stable temperature and humidity, and free access to feed and water. The rats were subjected to water maze test prior to enrollment, and those that had dyskinesia or cognitive impairment were excluded.

\section{Surgical procedure}

After anesthesia, the chests of rats in surgery, sevoflurane and fentanyl groups were cut open under auxiliary breathing, and their left coronary were arteries ligated within $30 \mathrm{~min}$, and then repassed for $2 \mathrm{~h}$. Changes in the appearances of their myocardia or occurrence of arrhythmia were carefully observed and noted, after which the chests were sutured. In the control group, rat chests were opened and their hearts exposed for $2 \mathrm{~h}$, and were sutured without coronary artery ligation.

\section{Administration of anesthesia}

Control and surgery groups: They received physiological saline for 7 days.
Sevoflurane group: Sevoflurane (2 \%) was inhaled for $2 \mathrm{~h} /$ day for 7 days.

Fentanyl group: The tail vein was injected with fentanyl at a dose of $50 \mu \mathrm{g} / \mathrm{kg}$ bwt, and venous pump was used to continuously pump the vein for $1 \mathrm{~h}$ for 7 days.

\section{Evaluation of cognitive function}

\section{Active avoidance learning ability test}

The rats were put in a shuttle box and permitted free movement for $5 \mathrm{~min}$ to eliminate exploration and reflection, after which they were set to start the buzzer. At the end of $20 \mathrm{sec}$ of activity, electric shock stimulation was given for $10 \mathrm{sec}$, and the rats either fled to the opposite shore, or turned off the buzzer and electric shock. Rats fleeing to safe areas within $10 \mathrm{sec}$ of buzzer activation were taken as having performed active avoidance. On the $30^{\text {th }}$ and $60^{\text {th }}$ days, the number of shocks and active avoidances were recorded and analyzed.

\section{Morris water maze (MWM) test}

The praxiological information of rats in the water maze was collected using ANY-maze video acquisition system. The rats were introduced into the pool at one of the four entries and different entries were used in a day. They were given 60 sec to find the site of the platform, and once they did, they remained there for another $10 \mathrm{sec}$. Rats unable to locate the platform within $60 \mathrm{sec}$ were put on it for $10 \mathrm{sec}$, and thereafter taken out of the pool. The escape latency of rats, from water to searching and climbing on the platform (index reflecting memory ability) was observed and recorded.

\section{Determination of levels of inflammatory factors}

After the evaluation of cognitive function on the $30^{\text {th }}$ and $60^{\text {th }}$ days, the rats were sacrificed in batches, and their brain tissues excised and stored at $-80{ }^{\circ} \mathrm{C}$. The brain tissues were homogenized in ice-cold saline, and subjected to centrifugation at $3000 \mathrm{rpm}$ for $10 \mathrm{~min}$. The resultant supernatants were used for determination of levels of inflammatory factors using ELISA kits.

\section{Statistical analysis}

Data are expressed as mean \pm SEM. Statistical analysis of data was carried out with SPSS (19.0). Group comparison was done with $f$-test. Statistical significance was fixed at $p<0.05$. 


\section{RESULTS}

\section{Cognitive function}

Table 1 shows that on the $30^{\text {th }}$ and $60^{\text {th }}$ days, the number of electric shocks were significantly higher in surgery, sevoflurane and fentanyl groups than in the control group. However, the number of active avoidances of electric shocks were significantly lower in surgery, sevoflurane and fentanyl groups, relative to control group $(p<$ 0.05 ). Active avoidances of electric shocks were significantly higher in sevoflurane and fentanyl groups than in the surgery group, but the sevoflurane group had significantly less avoidance than the fentanyl group $(p<0.05)$.

Table 1: Cognitive function in the various groups

\begin{tabular}{|c|c|c|c|c|}
\hline \multirow[t]{2}{*}{ Group } & \multicolumn{2}{|c|}{$\begin{array}{l}\text { Electric shocks } \\
\text { (time/min) }\end{array}$} & \multicolumn{2}{|c|}{$\begin{array}{c}\text { Active avoidance } \\
\text { of electric } \\
\text { shocks } \\
\text { (time/min) }\end{array}$} \\
\hline & Day 30 & Day 60 & Day 30 & Day 60 \\
\hline Control & $\begin{array}{c}53.41 \pm \\
9.72\end{array}$ & $\begin{array}{c}53.63 \pm \\
6.55\end{array}$ & $\begin{array}{c}86.49 \pm \\
7.74\end{array}$ & $\begin{array}{c}85.66 \pm \\
6.29\end{array}$ \\
\hline Surgery & $\begin{array}{c}91.33 \pm \\
5.75^{*}\end{array}$ & $\begin{array}{c}97.65 \pm \\
6.52^{*}\end{array}$ & $\begin{array}{l}51.07 \pm \\
10.24^{\star}\end{array}$ & $\begin{array}{c}50.86 \pm \\
7.05^{*}\end{array}$ \\
\hline Sevoflurane & $\begin{array}{c}73.27 \pm \\
6.83^{* \#}\end{array}$ & $\begin{array}{l}74.49 \pm \\
5.94^{* \#}\end{array}$ & $\begin{array}{l}78.86 \pm \\
9.49^{* \#}\end{array}$ & $\begin{array}{l}78.04 \pm \\
7.94^{* \#}\end{array}$ \\
\hline Fentanyl & $\begin{array}{l}85.62 \pm \\
7.68^{* \#}\end{array}$ & $\begin{array}{c}86.02 \pm \\
6.11^{* \#}\end{array}$ & $\begin{array}{c}66.08 \pm \\
9.53^{*} \#\end{array}$ & $\begin{array}{l}67.34 \pm \\
5.82^{* \#}\end{array}$ \\
\hline$f$ & 235.39 & 427.07 & 119.49 & 117.06 \\
\hline$p$ & 0.000 & 0.000 & 0.000 & 0.000 \\
\hline
\end{tabular}

\section{Outcomes of MWM test}

On the $30^{\text {th }}$ and $60^{\text {th }}$ days of the MWM test, learning and memory latencies of rats were significantly prolonged in surgery, sevoflurane and fentanyl groups, relative to sham-operated group $(p<0.05)$. In addition, learning and memory latencies of rats were significantly shorter in sevoflurane and fentanyl groups than in surgery group, and were shorter in sevoflurane group than in fentanyl group ( $p<0.05$; Table 2).

Table 2: Morris-water maze test results

\begin{tabular}{|c|c|c|c|c|}
\hline \multirow{2}{*}{ Group } & \multicolumn{2}{|c|}{$\begin{array}{l}\text { Learning } \\
\text { latency }(s)\end{array}$} & \multicolumn{2}{|c|}{$\begin{array}{r}\text { Memory } \\
\text { latency (s) }\end{array}$} \\
\hline & $\begin{array}{l}30^{\text {th }} \\
\text { day }\end{array}$ & $\begin{array}{l}60^{\text {th }} \\
\text { day }\end{array}$ & $\begin{array}{l}30^{\text {th }} \\
\text { day }\end{array}$ & $\begin{array}{l}60^{\text {th }} \\
\text { day }\end{array}$ \\
\hline Control & $\begin{array}{l}67.98 \pm \\
8.85\end{array}$ & $\begin{array}{l}68.77 \pm \\
7.32\end{array}$ & $\begin{array}{l}60.94 \\
\pm 5.88\end{array}$ & $\begin{array}{c}61.07 \pm \\
5.83\end{array}$ \\
\hline Surgery & $\begin{array}{l}177.68 \\
\pm 9.02^{*}\end{array}$ & $\begin{array}{l}178.09 \\
\pm 8.07^{*}\end{array}$ & $\begin{array}{l}153.94 \\
\pm 6.02^{*}\end{array}$ & $\begin{array}{l}152.60 \\
\pm 6.14^{*}\end{array}$ \\
\hline Sevoflurane & $\begin{array}{c}145.92 \\
\pm \\
10.07^{*}\end{array}$ & $\begin{array}{c}146.83 \\
\pm 7.99^{* \#}\end{array}$ & $\begin{array}{c}120.56 \\
\pm \\
5.95^{\star} \#\end{array}$ & $\begin{array}{l}121.73 \\
\pm 6.09^{*}\end{array}$ \\
\hline Fentanyl & $\begin{array}{l}158.86 \\
\pm 8.27^{*}\end{array}$ & $\begin{array}{l}160.07 \\
\pm 8.86^{\star \#}\end{array}$ & $\begin{array}{c}138.68 \\
\pm \\
5.98^{\star \#}\end{array}$ & $\begin{array}{l}139.08 \\
\pm 5.97^{*}\end{array}$ \\
\hline$f$ & 604.51 & 831.62 & 989.01 & 1061.15 \\
\hline$p$ & 0.000 & 0.000 & 0.000 & 0.000 \\
\hline
\end{tabular}

As shown in Table 3, TNF- $\alpha$ and VEGF were markedly higher in the surgery, sevoflurane and fentanyl groups, relative to the sham-operated group, and VEGF level was significantly higher in sevoflurane and fentanyl groups than in the surgery group $(p<0.05)$. Moreover, IL-6 was significantly upregulated in surgery, when compared to the fentanyl and sevoflurane groups.

\section{DISCUSSION}

Postoperative cognitive dysfunction which occurs in the elderly can delay their recovery from unconsciousness, significantly affect their quality of life, and may increase their mortality. Such cognitive decline can weaken the ability of organs to respond to surgical and traumatic stress. Sevoflurane and fentanyl are often used as anesthetics. However, there is limited evidence as to their involvement in the pathogenesis of postoperative cognitive dysfunction in elderly patients $[5,6]$.

Table 3: Levels of inflammatory factors in the various groups

\begin{tabular}{|c|c|c|c|c|c|c|}
\hline \multirow{3}{*}{$\begin{array}{l}\text { Group } \\
\text { Control }\end{array}$} & \multicolumn{2}{|c|}{ VEGF (ng/L) } & \multicolumn{2}{|c|}{ IL-6 (ng/L) } & \multicolumn{2}{|c|}{ TNF- $\alpha$ (ng/L) } \\
\hline & $30^{\text {th }}$ day & $60^{\text {th }}$ day & $30^{\text {th }}$ day & $60^{t h}$ day & $30^{\text {th }}$ day & $60^{t h}$ day \\
\hline & $53.09 \pm 3.21$ & $54.49 \pm 6.01$ & $14.67 \pm 2.98$ & $15.07 \pm 2.38$ & $17.15 \pm 3.28$ & $16.89 \pm 2.45$ \\
\hline Surgery & $65.27 \pm 4.02^{\pi}$ & $69.85 \pm 5.93$ & $29.11 \pm 3.12^{\pi}$ & $30.67 \pm 2.15^{\pi}$ & $34.82 \pm 4.06$ & $35.17 \pm 3.23^{\pi}$ \\
\hline Sevoflurane & $85.56 \pm 4.77^{\star \#}$ & $86.29 \pm 6.35^{\star \#}$ & $20.37 \pm 2.87^{\pi}$ & $21.05 \pm 2.97^{\star \#}$ & $23.68 \pm 3.97^{\approx \#}$ & $24.78 \pm 3.16^{\pi \#}$ \\
\hline Fentanyl & $78.32 \pm 3.96^{\prime \#}$ & $78.85 \pm 5.76$ \# & $22.26 \pm 3.20$ \# & $22.98 \pm 3.21$ \# & $27.52 \pm 3.45^{\star \#}$ & $28.55 \pm 3.76^{\prime \#}$ \\
\hline$f$ & 321.47 & 123.44 & 117.69 & 144.76 & 94.73 & 162.37 \\
\hline$p$ & 0.000 & 0.000 & 0.000 & 0.000 & 0.000 & 0.000 \\
\hline
\end{tabular}


In this investigation, MWM test revealed that the number of electric shocks were significantly higher in the surgery, sevoflurane and fentanyl groups than in control group. However, the number of active avoidances of electric shocks were significantly reduced in these groups than in control. The number of active avoidances of electric shocks were significantly higher in sevoflurane and fentanyl groups than in surgery group. The number of electric shocks was significantly lower in sevoflurane group than in fentanyl group. These results suggest that sevoflurane and fentanyl may exert some degree of protection on cognitive function in aged rats, and are in agreement with those previously reported [7-9]. Studies have shown that sevoflurane reduces myocardial infarct size via inhibition of the inflammatory response. The protective effect of sevoflurane on cognitive function in aged rats has been speculated to involve inhibition of the inflammatory response [10]. Increased levels of VEGF promote formation of blood vessels and nerves [11,12]. Interleukin-6 (IL-6), and TNF- $\alpha$ can directly or indirectly damage neurons of the hippocampus [13-15]. In this study, the levels of IL-6, VEGF and TNF- $\alpha$ were markedly higher in surgery, sevoflurane and fentanyl groups than in control group, and were significantly higher in sevoflurane and fentanyl groups than in surgery group. The level of IL-6 was significantly higher in surgery group than in fentanyl and sevoflurane groups. However, there were significant reductions in IL-6 and TNF- $\alpha$ levels in the sevoflurane and fentanyl groups, when compared with the surgery group. These results appear to suggest that sevoflurane and fentanyl may improve brain function in aged rats by reducing the levels of damaging inflammatory factors involved in the apoptosis of brain cells. These findings are consistent with those obtained in previous studies [16-18].

\section{CONCLUSION}

Sevoflurane and fentanyl improve cognitive function in aged rats through a mechanism involving the regulation of inflammatory response in the brain. This finding may also provide useful guides for the discovery of other therapeutic agents for improving cognitive function in the elderly through regulation of brain inflammation.

\section{DECLARATIONS}

\section{Conflict of interest}

No conflict of interest is associated with this work.

\section{Contribution of authors}

We declare that this work was done by the author(s) named in this article and all liabilities pertaining to claims relating to the content of this article will be borne by the authors. All authors read and approved the manuscript for publication. Peixiang Li conceived and designed the study, while Xin Zhao, Peixiang Li collected and analyzed the data. Xin Zhao wrote the manuscript.

\section{Open Access}

This is an Open Access article that uses a funding model which does not charge readers or their institutions for access and distributed under the terms of the Creative Commons Attribution License (http://creativecommons.org/licenses/by/ 4.0) and the Budapest Open Access Initiative (http://www.budapestopenaccessinitiative.org/rea d), which permit unrestricted use, distribution, and reproduction in any medium, provided the original work is properly credited.

\section{REFERENCES}

1. Zhao ZX, Zhang SD. Advances in research on postoperative cognitive dysfunction in anesthesia and elderly patients. Chin prescription drugs 2016; 14(8): 1112.

2. Lang SH, Xu WG, Liu X, Wang P, Meng JH. Relationship of postoperative serum $S 100 \beta \beta$ protein concentration and cognitive dysfunction in elderly patients underwent elective abdominal surgery. Ningxia Med J 2017; (12): 1147-1148.

3. Seyedabadi M, Rahimian R, Ghia JE. The role of alpha7 nicotinic acetylcholine receptors in inflammatory bowel disease: involvement of different cellular pathways. Expert Opin Ther Targets 2018; 22(2): 161-176.

4. World Health Organization. Principles of laboratory animal care. WHO Chron 1985; 39: 51-56.

5. Chen $G Z$, Lu KZ, Wang EQ, Tang $X$, Gu JT, Cui J, Tao GC. Effect of sevoflurane and propfol on postoperative cognitive function in elderly patients' recepted abdominal surgery. Chongqing Med 2010; 39(17): 22872289.

6. Sheng YF, Wu JX, Xu MY. Effects of anesthesia with propofol and sevoflurane on postoperative cognitive function of elderly patients undergoing thoracic surgery. J Shanghai Jiaotong Univ (Med Sci) 2011; 31(3): 322324.

7. Zhang YF, Feng YP, Lu XH, Li CS. The influence of sevofluen anesthesia in elderly patients with cancer of cognitive function after surgery for clinical anesthesia. Chin J Clin Oncol Rehabil 2011; 18(5): 470-472.

8. Wang F, Sun HI. Effect of Sevoflurane or Propofol Anesthesia on the Postoperative Cognitive Function of 
Senile Patients with Lung Cancer. China Foreign Med Treat 2017; 36(12): 131-133.

9. Liu L, Liu C, Zhong YB, Guo CH, Liu XF. Involvement of calcium influx in sevoflurane induced cognitive dysfunction. J Hainan Med Univ 2015; 21(5): 611-613.

10. Cao J, Hong $X$, Ying S, Zhu J, Ying M, Qiao SG, Shao Q, Wu HR, Wang $C$. Sevoflurane post-conditioning reduces rat myocardial ischemia reperfusion injury through an increase in NOS and a decrease in phopshorylated NHE1 levels. Int J Mol Med 2015; 36(6):1529-1537.

11. Kalaria RN. Neuropathological diagnosis of vascular cognitive impairment and vascular dementia with implications for Alzheimer's disease. Acta Neuropathol 2016; 131(5): 659-685.

12. Gasparovic C, Prestopnik J, Thompson J, Taheri S, Huisa B, Schrader R, Adair JC, Rosenberg GA. Research paper: $1 \mathrm{H}-\mathrm{MR}$ spectroscopy metabolite levels correlate with executive function in vascular cognitive impairment. J Neurol Neurosurg Psychiatry 2013; 84(7): 715-721.

13. Liang L, Ma Z, Dong M, Ma J, Jiang A, Sun X. Protective effects of salidroside against isoflurane-induced cognitive impairment in rats. Hum Exp Toxicol 2017; 36(12): 1295-1302.

14. Rosezyk HA, Sparkman NL, Johnson RW. Neuroinflammation and cognitive functioning aged mice follow minor surgery. Exp Gerontol 2008; 43(9): 840846.

15. Xu B, Li J, Cai XQ, Yang J. Effects of sevoflurane and fentanyl on long term cognitive function in aged rats. Acta Univ Med Anhui 2018; 53(1): 81-85.

16. Liu J, Liu SP, Gulinar KUERBAN, Chen JD. Toll-like receptor 3 signaling pathway plays an important role in cardiomyocyte apoptosis and inflammatory response in human viral myocarditis. Chin J Pathophys 2013; 29(3): 404-407.

17. Ling J, Li HR, Chen WL. Protein ubiquitination on the regulation of inflammatory bowel disease. J Zhejiang Univ (Med Sci) 2018; (1): 82-88.

18. Kang F, Tang C, Han M, Chai X, Huang X, Li J. Effects of Dexmedetomidine-Isoflurane versus Isoflurane Anesthesia on Brain Injury After Cardiac Valve Replacement Surgery. J Cardiothorac Vasc Anesth 2017; 32(4): 1581-1586. 